the tissues of beetroot and of the potato, when these are placed under certain abnormal ("unhygienic") conditions. And, though usually absent from the blood of persons suffering from specific contagious fevers, yet do we also find organisms invariably showing themselves in the blood of persons suffering from some of them-such as reiapsing fever and splenic fever. Nay, further, under the influence of a " change of conditions" alone, we may initiate these modified fermentative processes in vegetables - that is to say, in ordinary parlance, the processes may originate "spontaneously" or de novo. But if the modified activity of tissue-elements suffices to initiate such morbid processes in the vegetal organism, why may it not occasionally do the same in the animal organism? This is a point of view which seems too valuable to be lost sight of, more especially in the face of the results yielded by our flask experiments.

3. In conclusion, I would maintain that the facts already known abundantly suffice to displace the narrow and exclusive vital theory, and to re-establish a broader physico-chemical theory of fermentation.

Whether the "ferment" in any given case be an independent living organism, a tíssue-element, a fragment of not-living organic matter, or some mere physico-chemical influence (as in the case of the action of finely divided platinum), the initiative fermentative change is in each case a result of chemical action. And similarly, with regard to "contagium", whether it be an altered though living tissue-element, a fragment of dead organic matter, a chemical compound (or even the more vague influence of a "set of conditions", which may suffice to generate contagium de nov'o), we have in each case to do with gradually initiated chemical changes, distinctive in kind, and gradually terminating in one or other of the recognised varieties of zymotic affections. The changes in each case where we happen to have to do with living ferments or living contagia would be due only to an infinitesimal extent to the organic multiplication of such living units, though the decompositions set up by them in their respective fluids may be such as to lead to the formation of a continuous new birth of independent organisms, all of which exhibit most active powers of multiplication. The organisms produced in such cases are, therefore, only to an infinitesimal extent lineal descendants of the original living ferments or contagia, under whose influence such fermentative or zymotic processes were originally established. (Besinnings of Life, vol. ii., p. 36r.)

Thus it would appear that the original notion borrowed from the vital theory of fermentation, that all the organisms met with in a fermenting mixture are in the strict sense of the term lineal descendants of those originally introduced as ferments, would disappear with the vital theory itself. Yet this has been the notion upon which upholders - of the germ-theory of disease have always relied confidently, in explanation of the mode of increase of contagium within the body.

Looking, however, at this question from our new point of view, may we not say that chemical changes established in some one tissue, or in many, may, by dint of altered blood and other secondary processes, spread so as to be initiated also in previously sound parts; and that thus throughout the body, or in some special regions of it, living tissue, endowed with peculiar poisonous properties, or complex alkaloidal compounds, may be engendered in enormous quantities, some of which may be thrown off from this or that surface, and act after the fashion of "contagia" generally.

\section{THE TEMPERATURE IN PHTHISIS}

SHORTIy after the publication of Dr. Sidney Ringer's work on the Use of the Thermometer in Phthisis, I made a number of thermal observations on phthisical patients, and came to the conclusion that valuable as the thermometer is in the diagnosis of a variety of diseases, yet, as a test of the deposition of tubercle, it is unreliable. In cases of incipient phthisis, with obscure physical signs, it did not aid the diagnosis; it was unsafe to say that there was no disease because the temperature was normal. In many cases, there was no rise, yet signs of tubercular deposit gradually unfolded themselves. In others, a rise of two or three degrees occurred, but often there was slight bronchial inflammation which might account for it. In more advanced cases, there was of course softening, and often subacute pneumonia, bronchitis, etc. I believe that the thermometer indicated only the pyrexia produced by these complications. Subnormal temperature was occasionally observed when the vital powers were low. I several times intended to record these observations, but feared they were not sufficiently elaborate to satisfy the profession, although they convinced me. Dr. Theodore Williams has now more efficiently done so; and it is satisfactory to find his conclusions tally with mine.

H. Strangways Hounsell, M.D., M.R.C.P.Lond., Physician to the Western Hospital for Consumption, Erith House Institution, etc., Torquay.
ON THE ACTIONS OF PICROTOXINE, AND THE

\section{ANTAGONISM BETWEEN PICROTOXINE AND} CHLORAL HYDRATE.

BY J. CRICHTON BROWNE, M.D., F.R.S.E., Medical Director of the West Riding Asylum.

\section{(Continued from page 444.)}

CERTAIN conclusions having thus been arrived at as to the actions of picrotoxine and as to the toxic symptoms produced by it when uninterfered with by treatment, it became necessary in the next place to ascertain accurately the minimum fatal dose of it, in those animals which it was proposed to make use of, in testing the supposed antagonism between it and chloral hydrate. The results of the experiments which were performed with this view are shown in the two following tables.

TabLe II.-Showing the Mrinimum Futal Dose of Picrotoxine in Rabbits.

\begin{tabular}{|c|c|c|c|c|}
\hline No. & $\begin{array}{l}\text { Weight } \\
\text { of } \\
\text { Rabbits. }\end{array}$ & 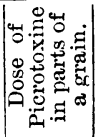 & Effects. & Result. \\
\hline 9 & $2 \mathrm{lbs} .6 \mathrm{oz}$ & 1-60th & Dulness, hurried breathing, and pro- & Recovery \\
\hline 10 & $3 \mathrm{lbs} .2 \mathrm{oz}$. & 1-10th & Lethargy and unsteadiness in move- & " \\
\hline 11 & $3 \mathrm{lbs} .2 \mathrm{oz}$. & $1-30$ th & $\begin{array}{l}\text { ments } \\
\text { Dulness, quickened respiration, rest- } \\
\text { lessness, twitching of ears }\end{array}$ & " \\
\hline 12 & 3 lbs. 7 oz. & 1-25th & $\begin{array}{l}\text { Lethargy, hurried respiration, twitch- } \\
\text { ings. }\end{array}$ & " \\
\hline 13 & 3 lbs. 9 oz. & 1-25th & $\begin{array}{l}\text { Prostration, hurried respiration, se- } \\
\text { vere twitchings }\end{array}$ & , \\
\hline 14 & 3 lbs. 3 oz. & 1-20th & $\begin{array}{l}\text { Lethargy, restlessness, violent con- } \\
\text { vulsions }\end{array}$ & Death in $81 \mathrm{~min}$. \\
\hline 15 & $2 \mathrm{lbs} .12 \mathrm{oz}$. & $1-20 \operatorname{th}$ & Dulness, twitchings, violent convul- & Death in $75 \mathrm{~min}$. \\
\hline 16 & $3 \mathrm{lbs} .3 \mathrm{oz}$ & 1-8th & $\begin{array}{l}\text { Lethargy, hurried breathing, trem- } \\
\text { bling, violent convulsions }\end{array}$ & Death in $32 \mathrm{~min}$. \\
\hline 17 & 2 lbs. 2 oz. & $1-3 \mathrm{rd}$ & $\begin{array}{l}\text { Drowsiness, twitchings, violent con- } \\
\text { vulsions }\end{array}$ & nin. \\
\hline 18 & $2 \mathrm{lbs} .15 \mathrm{oz}$. & $2-3$ rds & $\begin{array}{l}\text { Staggering, loss of power in legs, } \\
\text { violent convulsions }\end{array}$ & Death in $19 \mathrm{~min}$. \\
\hline
\end{tabular}

Table III.-Showing the Minimun Fatal Dose of Picrotoxine in Guinea-Pigs.

\begin{tabular}{|c|c|c|c|c|}
\hline No. & $\begin{array}{l}\text { Weight of } \\
\text { Guinea- } \\
\text { Pig. }\end{array}$ & 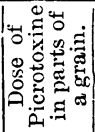 & Effects. & Result. \\
\hline 19 & $1 \mathrm{lb} .2 \mathrm{oz}$. & 1-55th & $\begin{array}{l}\text { Lethargy, followed by restlessness, } \\
\text { with twitchings of ears }\end{array}$ & Recovery \\
\hline 20 & $1 \mathrm{lb} .6 \mathrm{oz}$. & 1-50th & $\begin{array}{l}\text { Dulness, quickened respiration, } \\
\text { twitchings of ears and mouth }\end{array}$ & " \\
\hline 21 & $1 \mathrm{lb} .4 \mathrm{oz}$ & 1.40th & $\begin{array}{l}\text { Dulnes, hurried respiration, twitch- } \\
\text { ings, three severe fits, with tonic } \\
\text { and clonic spasms }\end{array}$ & " \\
\hline 22 & $1 \mathrm{lb} .5 \mathrm{oz}$. & $1-35$ th & $\begin{array}{l}\text { Lethargy, restlessness, twitchings of } \\
\text { ears and mouth, loss of power in } \\
\text { hind legs }\end{array}$ & , \\
\hline 23 & $1 \mathrm{lb} .5 \mathrm{oz}$. & $1-30$ th & $\begin{array}{l}\text { Drowsines, hurried breathing, rest- } \\
\text { lessness, three fits, then constant } \\
\text { convulsions }\end{array}$ & Death in $123 \mathrm{~m}$. \\
\hline 24 & $1 \mathrm{lb} .2 \mathrm{oz}$. & 1-30th & $\begin{array}{l}\text { Lethargy, twitchings, violent con- } \\
\text { vulsions }\end{array}$ & Death in $62 \mathrm{~min}$. \\
\hline 25 & $1 \mathrm{lb}$. & 1-30th & $\begin{array}{l}\text { Liveliness, startings, violent convul- } \\
\text { sions }\end{array}$ & Death in $40 \mathrm{~min}$. \\
\hline 26 & $1 \mathrm{lb} .2 \mathrm{oz}$. & 1.20 th & $\begin{array}{l}\text { Lethargy, twitchings, violent con- } \\
\text { vulsions }\end{array}$ & Death in $75 \mathrm{~min}$. \\
\hline 27 & $1 \mathrm{lb} .6 \mathrm{oz}$. & 1-4th & $\begin{array}{l}\text { Lethargy, hurried breathing, start- } \\
\text { ings, violent convulsions }\end{array}$ & Deathin 25 min. \\
\hline
\end{tabular}

These tables demonstrate that one-twentieth of a grain of picrotoxine may be regarded as the minimum fatal dose in a rabbit weighing about three pounds, and that one-thirtieth of a grain may be regarded as the minimum fatal dose for a guinea-pig weighing about a pound and a quarter. This point having been satisfactorily settled, the next experiment was directed to ascertain whether, as had been supposed, the action of the picrotoxine could be modified or controlled by chloralhydrate.

Experiment xxviII.-A vigorous rabbit, weighing exactly three pounds, was procured, and to it one-twentieth of a grain of picrotoxine was administered by hypodermic injection, ten grains of chloral-hydrate being simultaneously administered in the same way. Ten minutes after the injection, the rabbit was heavy and dull; and, five minutes later, its bowels having in the meantime acted very freely, there was superadded to the dulness some drowsiness. It still rested upon its feet, but its kead drooped to one side. The breathing was exceedingly rapid. Twenty minutes after the injection, it was drowsy, but still sitting up, and able to move away at once when pinched or disturbed. The 
respirations were at the rate of $\mathrm{I} 40$ per minute, and somewhat irregular. Forty minutes after the injection, it remained in nearly the same condition, except that it was stretched out upon the floor, and looked more prostrated. It did not scream when its tail was pinched, but simply moved away from the annoyance. Fifty minutes after the injection, it was umeasy, and frequently changed its position. It was still sitting up, and able to move about, though with some unsteadiness. Seventy minutes after the injection, it lay upon its belly, with its limbs stretched out, but could still spring on to its feet when disturbed. Ninety minutes after the injection, it got up voluntarily, and sought out a dark corner, in which it ensconced itself. One hundred and twenty minutes after the injection, it was quite well, and eating freely. From first to last, there were no tremblings, no spasms of any kind, and no deep sleep nor coma.

Experiment Xxix.-A guinea-pig, weighing I lb. 4 oz., had onethirtieth of a grain of picrotoxine injected at the same time with five grains of chloral-hydrate. In seven minutes, it was very drowsy, and in eleven minutes it was sleeping quietly. In twenty-six minutes, its sleep was unquiet, and it often awoke, got up, changed its position, and then dropped off to sleep again, its breathing all the time being very rapid. In forty minutes, it was awake, looking about it, and moving a good deal. In fifty minutes, it had again fallen into a sleep; from which, however, it could be readily roused. In seventy minutes, it was still asleep, but restless, and tossing about from time to time. In ninety minutes, it was sleeping quietly; and in this state it remained until three hours after the injection, when it awoke up quite recovered. From first to last, there were no spasms, and no profound comatose sleep.

These two experiments were regarded as very remarkable, and as clearly indicating the existence of the antagonism which had been sus pected. It was felt, however, that a much larger body of proof was requisite for its full demonstration ; and accordingly the series of experiments summarised in the following tables was next undertaken.

TABLR IV.-Shouing the Effects of the Hydrate of Chloral Injected with Fatal Doses of Picrotoxine in Rablits.

\begin{tabular}{|c|c|c|c|c|c|}
\hline No. & $\begin{array}{l}\text { Weight } \\
\text { of } \\
\text { Rabbit. }\end{array}$ & 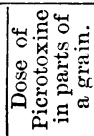 & 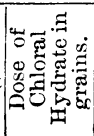 & Effects. & Result. \\
\hline 30 & $2 \mathrm{lbs} .14 \mathrm{oz}$. & $1-20$ th & 10 & $\begin{array}{l}\text { Drowsiness, disturbed sleep } \\
\text { for two hours }\end{array}$ & Recovery \\
\hline 31 & 3 lbs. 1 oz. & $1-20$ th & 12 & $\begin{array}{l}\text { Drowsiness, hurried breath- } \\
\text { ing, deep sleep for } 2 \text { hours }\end{array}$ & ", \\
\hline 32 & $2 \mathrm{lbs} .8 \mathrm{oz}$ & $1-16$ th & 15 & $\begin{array}{l}\text { Drowsiness, sleep easily dis- } \\
\text { turbed }\end{array}$ & ", \\
\hline 33 & $3 \mathrm{lbs}$. & 1-15th & 12 & $\begin{array}{l}\text { Prostration, hurried breath- } \\
\text { ing, twitchings of head and } \\
\text { ears }\end{array}$ & ", \\
\hline 34 & 3 lbs. 4 oz. & $1-8$ th & 15 & $\begin{array}{l}\text { Dulness, hurried breathing, } \\
\text { twitchings, five severe fits }\end{array}$ & , \\
\hline 35 & 3 lbs. $6 \mathrm{oz}$ & $1-4$ th & 21 & $\begin{array}{l}\text { Twitchings, convulsions, } \\
\text { drowsiness, deep sleep }\end{array}$ & ", \\
\hline 36 & $2 \mathrm{lbs} .13 \mathrm{oz}$. & $1-3 \mathrm{rd}$ & 20 & $\begin{array}{l}\text { Drowsiness, lethargy, twitch- } \\
\text { ing, violent convulsions }\end{array}$ & Death in $24 \mathrm{hrs}$. \\
\hline 37 & 2 lbs. $14 \mathrm{oz}$ & ono-half & 20 & $\begin{array}{l}\text { Drowsiness, hurried breath- } \\
\text { ing, twitchings, violent con- } \\
\text { vulsions }\end{array}$ & Death in $6 \mathrm{hrs}$. \\
\hline 38 & 2 lbs. 14 oz. & $2-3 \mathrm{rds}$ & 21 & $\begin{array}{l}\text { Restlessness, hurried breath- } \\
\text { ing, drowsiness, sleep, } \\
\text { twitchings, violent convul- } \\
\text { sions }\end{array}$ & Death in $59 \mathrm{~m}$. \\
\hline
\end{tabular}

TABLE V.-Showing the Effects of the Hydrate of Chloral when Injected with Fatal Doses of Picrotoxine in Guinea-Pigs.

\begin{tabular}{|c|c|c|c|c|c|}
\hline No. & $\begin{array}{l}\text { Weight of } \\
\text { Guinea- } \\
\text { Pig. }\end{array}$ & 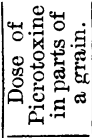 & 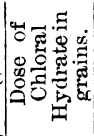 & Effects. & Result. \\
\hline 39 & $1 \mathrm{lb} .12 \mathrm{oz}$. & $1-30$ th & 5 & $\begin{array}{l}\text { Drowsiness, sleep, but not so } \\
\text { profound as chloral sleep } \\
\text { usually is }\end{array}$ & Recovery \\
\hline 40 & $1 \mathrm{lb} .4 \mathrm{oz}$. & 1-30th & 5 & $\begin{array}{l}\text { Drowsiness and disturbed } \\
\text { sleep }\end{array}$ & $"$ \\
\hline 41 & $1 \mathrm{lb} .6 \mathrm{oz}$. & $1-20$ th & 6 & $\begin{array}{l}\text { Drowsiness, restless, dis- } \\
\text { turbed sleep }\end{array}$ & $"$ \\
\hline 42 & $1 \mathrm{lb} .2 \mathrm{oz}$. & 1-16th & 7 & $\begin{array}{l}\text { Drowsiness, restlessness, } \\
\text { twitchings, broken sleep }\end{array}$ & " \\
\hline 43 & $1 \mathrm{lb} .4 \mathrm{oz}$. & 1-8th & 10 & $\begin{array}{l}\text { Drowsiness, twitchings, vio- } \\
\text { lent convulsions }\end{array}$ & Death in $4 \mathrm{hrs}$. \\
\hline 44 & $1 \mathrm{lb} .7 \mathrm{oz}$. & 1-8th & 8 & $\begin{array}{l}\text { Lethargy, restlessness,twitch- } \\
\text { ings, hurrried breathing, } \\
\text { coma }\end{array}$ & $\begin{array}{l}\text { Death in } 10 \mathrm{hrs} . \\
\text { and } 40 \mathrm{~min} .\end{array}$ \\
\hline $\begin{array}{l}45 \\
46\end{array}$ & $\begin{array}{l}1 \mathrm{lb} .3 \mathrm{oz} . \\
1 \mathrm{lb} .7 \mathrm{oz} .\end{array}$ & $\begin{array}{l}1.4 \text { th } \\
1.4 \text { th }\end{array}$ & $\begin{array}{r}10 \\
. \quad 6\end{array}$ & $\begin{array}{l}\text { Drowsiness, deep sleep, coma } \\
\text { Restlessness, startings, con- } \\
\text { vulsions }\end{array}$ & $\begin{array}{l}\text { Death in } 7 \mathrm{hrs} \text {. } \\
\text { Death in } 90 \mathrm{~m} \text {. }\end{array}$ \\
\hline
\end{tabular}

As these experiments progressed, it became abundantly evident that chloral-hydrate counteracts the effects of poisonous doses of picrotoxine in the most decisive manner, and that the antagonism which exists between them is one of the most striking instances of antagonism that has yet been discovered. For, whereas the largest dose of strychnia which has yet been antagonised by chloral-hydrate in a rabbit-onefortieth of a grain-is just about equal to two minimum fatal doses, the largest dose of picrotoxine that has been so antagonised-one-fourth of a grain-is equal to five minimum fatal doses; and, whereas the pro. longation of life in the rabbit by chloral-hydrate after doses of strychnia, which it was powerless altogether to antagonise, has never exceeded eight times the period in which life is destroyed by the same dose of strychnia unmodified by treatment, the prolongation of life in the rabbit by the same agent, after doses of picrotoxine under similar circumstances, has amounted to as much as forty-eight times the period in which death would have ensued, had the picrotoxine been uninter. fered with in its action.

When the minimum fatal dose of picrotoxine-one-twentieth of a grain-was administered, and with it ten or twelve grains of hydrate of chloral, the rabbit, instead of dying in about an hour and a half after violent convulsions, perfectly recovered after a more or less disturbed sleep of two or three hours' duration; and the same rabbit that thus recovered was killed about a week later by the repetition of the same dose of picrotoxine-one-twentieth of a grain given alone-within one hour and a half of its administration. When onefifteenth or sixteenth of a grain of picrotoxine was given with twelve or fifteen grains of chloral, perfect recovery took place after a prolonged sleep, broken in upon by restlessness and trifling twitchings. At and beyond this point, no crucial experiment, consisting in the repetition of the same dose of the poison, after a suitable interval, without the antidote, was deemed necessary. Such an experiment, indeed, would have been but an useless waste of life, as I have never seen a rabbit recover after a sixteenth of a grain of picrotoxine. Having received such a dose, rabbits invariably die within an hour, after severe convulsions. When one-eighth of a grain of picrotoxine was administered with twelve grains of hydrate of chloral, satisfactory recovery took place, but after a succession of symptoms which revealed outwardly in a singular manner the struggle for the possession of the nervous system which was going on within by the two opposing agents. So nearly were their forces matched in this instance, that the conflict was severe and long maintained, and the ascendancy was gained by each in turn; the victory, however, finally falling, not to the bane, but to the antidote. The drugs were administered at 3.30 P.M., and ten minutes thereafter the rabbit was drowsy, its head nodding, and its breathing being exceedingly rapid. In eighteen minutes, it was lively, and able to move about; but in twentyfour minutes it was very feeble, and swayed visibly when it attempted to walk. In twenty-five minutes, there were shakings of the head from side to side, and twitchings of the ears, lasting just six seconds. The instant these movements terminated, the animal manifested great drowsiness, nodded repeatedly, and then let its head fall flaccid on one side. In twenty-eight minutes, sleep having lasted for three minutes, there were a start and sudden awakening, and then drawing back of the head and rapid twitchings of the ears and mouth, continuing eight seconds, and again merging into sleep. In thirty-three minutes, there occurred another seizure. This time the head was drawn back, the fore-paws were spread out, and the body then reared aloft on them; while the lips and ears were sharply agitated. During the fit, pinching the tail secured no response; but whenever the fit was over, and the animal had fallen asleep, the same irritation caused wakening and movement, but no cries. 'The breathing immediately before and after the fit was so rapid as to be uncountable; but during the interparoxysmal sleep it became gradually slower. In thirty-six minutes, there was another fit like the preceding, except that the head was drawn to the right side. At the close of this fit, and before the supervention of sleep, there was a sharp attack of sneezing. In forty minutes, there was another fit, in which the head was violently shaken, and in which the munching movements were very vigorous. In the sleep of four minutes' duration which followed upon this fit, there was occasional slight shaking of the head (the rabbit was still in a sitting attitude), which did not, however, interrupt sleep. In forty-four minutes, there was another slight attack of clonic spasms, limited to the head, and accompanied by a free flow of saliva from the mouth. Subsequently to this, no twitchings occurred; the rabbit fell into a deep sleep, which lasted for an hour and a half; and then it awoke and began to scramble about. It remained in a feeble and. stupid state for three hours more, and was not altogether well until next morning.

In this case, the dose of chloral-hydrate given was rather too small, absolutely, and from the first, to counterbalance the effects of the 
picrotoxine, so that the contest between them became visible. Had twenty instead of fifteen grains of chloral-hydrate been administered, it is probable that no fits would have occurred.

When one-fourth of a grain of picrotoxine and twenty-one grains of chloral-hydrate were injected simultaneously, the phenomena observed were very like those described above, except that, after about a dozen separate fits and intermediate sleep harassed by frequent twitchings, there was a short period of continuous clonic spasms, in which, for about three minutes, the head was drawn back, and the fore-paws went through active running movements, which were arrested by deep and protracted sleep. When still larger doses of picrotoxine were administered to rabbits, as one-third, one-half, and two-thirds of a grain, with from twenty to twenty-four grains of chloral, evidences were not wanting of the extraordinary power of the latter drug to modify, arrest, and mitigate the effects of the former. Although, in these cases, the chloral-hydrate failed to ward off death, it marvellously extended life, and reduced the severity of the most distressing symptoms. With such enormous doses of picrotoxine, much larger doses of chloral-hydrate than were resorted to would be called for, in order to render it efficacious as an antidote-doses so large, indeed, as to be in themselves poisonous to a degree not to be counterbalanced by picrotoxine. The rabbits that received these enormous doses perished from the picrotoxine and an insufficiency of chloral. In one, life was drawn out and slight twitchings persisted for twenty-four hours, death then being due to exhaustion; and, in the other, death was due to the terrible convulsions and their immediate consequences.

[To be continued.]

\section{THERAPEUTIC MEMORANDA.}

\section{INTERNAL ADMINISTRATION OF TAR IN PSORIASIS.}

IT may not be out of place if I avail myself of the opportunity afforded by the publication in the JOURNAL of March 2oth, of the researches of Dr. Ringer and Mr. Murrill into the value of the ingestion of tar in wintercough, to state the results of an investigation as to the value of the ingestion of tar in psoriasis. A distinguished teacher, under whom both Dr. Ringer and I studied, was in the habit of treating his cases of psoriasis with tar administered simultaneously internally and externally, and used to impress the memory of the fact on the minds of his class by telling them that such patients should be done to as Noah did to his ark; that is to say, they should be pitched within and without; and his patients certainly did well under the treatment. This led me to feel curious to know which of the two was the more important-pitching within or pitching without. I accordingly, as soon as I had hospital patients of my own, dealt with all my cases of psoriasis for some time as follows. The first had tar-ointment and camphor mixture; the second had tar internally in the shape of tar-capsules, without other treatment of any kind ; the third was treated like the first ; and so on with about thirty cases in all - the odds being simply pitched without, the evens being impartially pitched within. At the end of a couple of months, a very decided result was obtained. Those pitched without had all very con. siderably improved, and some were perfectly well. Those pitched within remained very much as before, some of them being even worse than at first. To obviate the possible contingency of those pitched within being obstinate cases, they were next pitched without, and they all of them thereupon began speedily to undergo improvement. In administering tar internally in this experiment, I pushed it in every case ad nauseam. I began with a stronger dose than an ordinary tar-pill, namely, a tar-capsule three times a day. I increased this dose by doubling it, and then by trebling it in cases where it could be borne without excessive nausea ; but in no case did it seem to do the least perceptible good. The experiments of so pre-eminently able an observer of the action of drugs as Dr. Ringer prove without question that tar is capable of producing an effect on organs remote from those to which it is applied. I am unable, therefore, to offer any explanation of the results I arrived at. I can only offer my experiment to him, in the hope that he may think it worth while to repeat it and report whether or not I am correct in my conclusion, that tar taken internally has no effect in curing psoriasis, although its local application to the disease has in all cases a decidedly beneficial effect, and in many is of itself sufficient to cause the complete disappearance of the eruption.

Balmanno SQUiRe, M.B.

\section{ON THE USE OF DIGITALIS IN THE TREATMENT OF} SOME CASES OF BRONCHITIS.

Given a patient past the meridian of life, either very stout, or emaciated from previous bad health, and let him, or more commonly her, have a neglected bronchitis, and we have the following class of symptoms produced : A perspiring skin, a poor and quick pulse, urgent dyspnœa, bluish tinge of lips and skin, and respiration accompanied by loud wheezing sounds. The most successful plan of treating these cases, so common during the present severe winter, is the free administration of digitalis, which may be advantageously combined with the compound spirit of ammonia. The digitalis may be given in doses of ten minims of the tincture every two hours. In less urgent cases, the pills recommended by Dr. Fothergill, in his Hastings prize essay published in this JourNAL, are very useful, and have the advantage of less easily inducing sickness than the tincture. In these cases, it is the heart which is at fault, the right ventricle being gorged with blood, which it is unable to propel through the lungs. The best test of the truth of this theory is its success, for the pulse will be found to become full and slow, and the breathing relieved, directly the digitalis has had time to act on the heart. Its action is sometimes assisted by the judicious administration of a little alcohol. I prefer common gin. If, however, it be found that these cases of commonly called bronchitis are really dependent, for their non-recovery at least, upon weak hearts, care must be taken as to the administration of stimulants, for they accelerate the action of the heart, and in the end weaken it. In fact, digitalis slackens the speed, and stimulants increase it, so they to some extent contradict each other. I have had some cases lately in which twenty minims of tincture of digitalis were given every two hours for a whole day, and then decreased to ten minims every four or six hours. This medicine will be found to be chiefly valuable when the pulse is weak and rapid. In one old lady about 80 years of age, the effect was remarkable, and in another, seen to-day, the pulse has fallen to 76 , with corresponding relief to the other symptoms. In another case, in which the pulse was 130 and very weak, it acted magically, but I am sorry I made no note of the exact rate to which the pulse fell. Good support of all kinds may at the same time be given. I like stimulants less and less in this form of disease; if you want a horse to go one mile rapidly and well, the spurs may be used, but for a long journey a steady pace is better. Some patients are more susceptible of digitalis than others, therefore the effects must be watched, and the dose increased or diminished, as necessary.

James BRaithwaite, M.D., Lond., M.R.C.S.,

Assistant-Surgeon to the Hospital for Women and Children, Leeds.

\section{REPORTS}

\section{MEDICAL AND SURGICAL PRACTICE IN THE HOSPITALS OF GREAT BRITAIN.}

\section{ALL SAINTS INSTITUTION, GOWER STREET. CASES OF OVARIOTOMY.}

(Under the care of Dr. Graily HewitT.) (Continued from page 478.)

CASE xi. Multilocular Cystic Tumour of Ovary: Considerable Adhesions: Ovariotomy: Recovery. (Reported by Mr. A. P. GoulD, M.B.) - C. F., single, aged 40, had been under the care of Dr. Trouncer of Surbiton. She had had suppression of the catamenia for one year from cold at the age of I4. Since that time, she had been rather irregular. She was liable to cedema of the legs and feet. Eight months ago, after some exertion, she felt " ricked" in the side, and retention of urine occurred for one day. Six weeks later, she had a fall, and struck the side, soon after which the abdomen began to increase in size. On July I9th, 1874, she had menstruated last two months ago. She was emaciated. There was considerable œedema of the legs. The abdomen was much enlarged, more on the left than on the right side. Fluctuation was distinct, and limited to the area of dulness. The flanks were resonant. A vertical groove divided the tumour into two parts. The whole mass within the abdomen reached nearly to the ensiform cartilage.

On July 3oth, ovariotomy was performed in the presence of Dr. Trouncer and others, Dr. John Williams assisting, together with Mr. B. P. Gould and Mr. D. Edwards. Ghloroform was given by $\mathrm{Mr}$. Meredith. The incision extended to the umbilicus. Adhesiens inextricably confused the recognition of the peritoneum, and three cysts were punctured, allowing each about one pint and a half of thick tenacious fluid to escape. The tumour was then found to be universally adherent over its anterior aspect, some of the adhesions above being very firm. The tumour, when finally turned out, was found to proceed from the right ovary, its pedicle being a broad one. An artery as large 